\title{
Priscilla Renouf Remembered: An Introduction to the Special Issue with a Note on Renaming the Palaeoeskimo Tradition
}

\author{
Lisa Hodgetts ${ }^{1}$ and Patricia Wells ${ }^{2}$
}

\section{REMEMBERING PRISCILLA RENOUF}

Arctic archaeology lost a great friend when Priscilla Renouf lost her battle with cancer on 4 April 2014. Priscilla devoted her career to understanding past human occupation on Newfoundland's Great Northern Peninsula, particularly at Port au Choix. She furthered our understanding of the Maritime Archaic, Recent Indian, Groswater, and Dorset occupations of the region, and her enthusiasm for the subject inspired many students to follow in her footsteps. Priscilla loved the problem solving and comradery of fieldwork, expanding our knowledge of Newfoundland prehistory, and helping to shape the direction of Canadian heritage and research. Everyone who ever shared a drink with her after a day's fieldwork will remember her for her energy, her inquisitive nature, her wicked sense of humour, and her gift for making the past come to life. She was a great friend and mentor to many of us, and she will be sorely missed.

\section{Priscilla's Childhood and Education}

Priscilla was born on 8 August 1953 and grew up on a quiet street near downtown St. John's, Newfoundland. Her neighbourhood during those years was populated with an abundance of girls, who moved easily among the houses, cementing friendships that would last a lifetime. Along with her three sisters, she attended an all-girl convent school. The nuns who taught them instilled a strong sense of duty to strive for scholastic excellence, and so did Harry, Priscilla's father, who encouraged academic competition amongst all the girls. The Renouf household was a popular retreat where the girls could enjoy the relaxed and affectionate matriarch Mimi, and the more formidable yet ever-charming Harry. He often joked about the hardships of being the sole male in a house full of strong-willed girls. Once a friend bought him a canary guaranteed to be male that went on, a few weeks later, to produce eggs. Harry's gift of mixing humour with encouragement was something Priscilla inherited, to the benefit of the many students she later supervised.

In 1970, Priscilla began her studies at Memorial University, where her school friend Marcie Madden

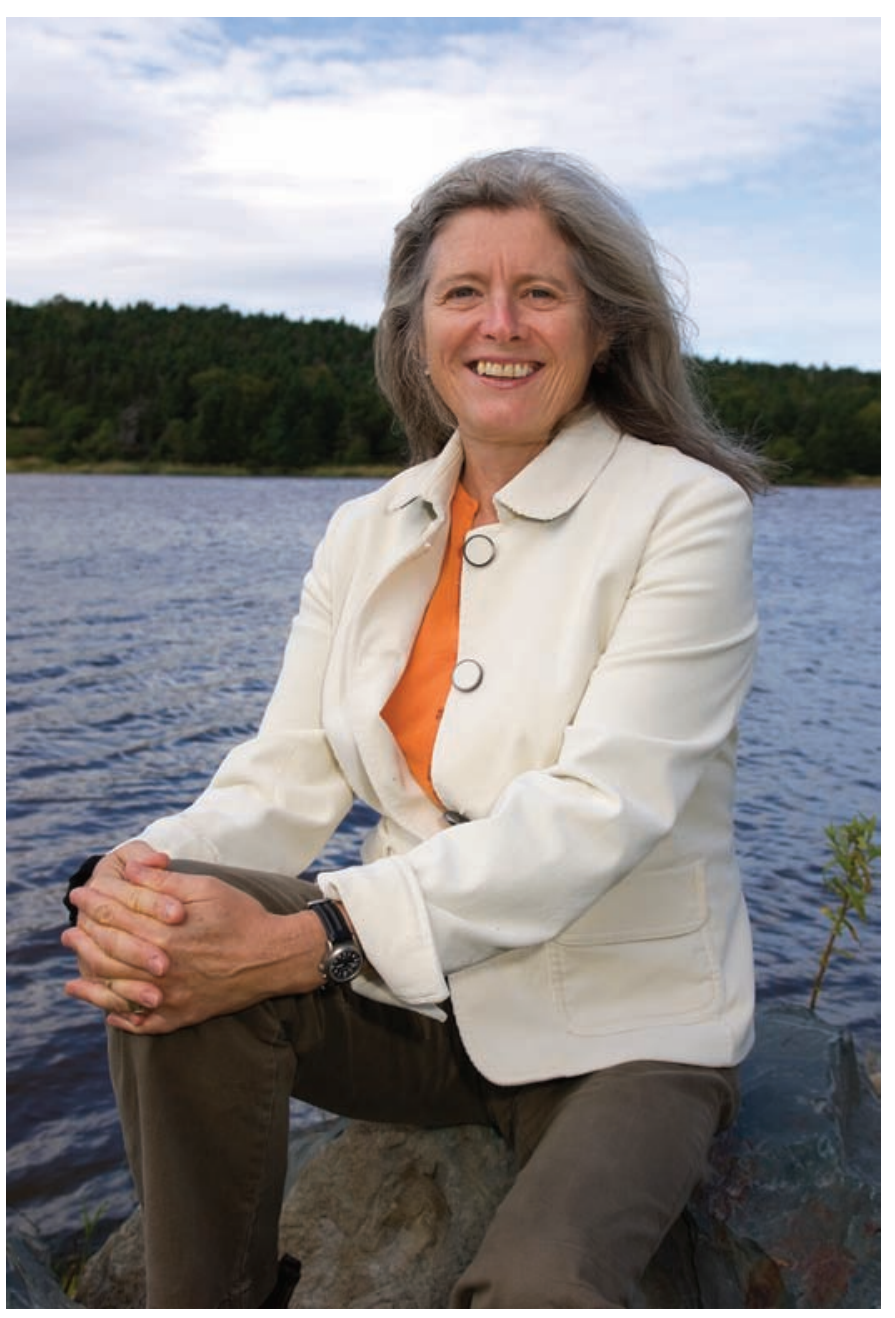

Priscilla Renouf. Reprinted with permission from Memorial University of Newfoundland.

persuaded her to take archaeology. She found the analysis of material remains very appealing, but was particularly drawn to the process of carefully revealing the cultural practices of the pre-contact hunter-gatherers she studied. Along with Marcie, she completed her undergraduate and master's degrees at Memorial. Encouraged by their supervisor, Jim Tuck, both went on to pursue doctoral research at the University of Cambridge. There, Priscilla

\footnotetext{
${ }^{1}$ Department of Anthropology, Western University, Social Science Centre, London, Ontario N6A 5C2, Canada;

lisa.hodgetts@uwo.ca

${ }^{2}$ The Arctic Institute of North America, University of Calgary, 2500 University Drive NW, Calgary, Alberta T2N 1N4, Canada; patricia.wells@ucalgary.ca

(C) The Arctic Institute of North America
} 
made lifelong friendships with many of her cohort. She was one of the last students supervised by Grahame Clark, an expert on the European Mesolithic who helped pioneer the "New Archaeology," framing archaeology as the scientific study of interactions between people and their environments. Her $\mathrm{PhD}$ thesis examined the settlement and subsistence patterns of past hunter-gatherers on the northern coast of Norway.

\section{Priscilla's Career at Memorial}

Priscilla returned to Memorial University in 1981 to take up a faculty position in the Department of Anthropology. In 1984, she initiated a program of field research at Port au Choix that continued, with only a few short interruptions, until her death. For more than two decades, she poured herself into her work, often working nights, weekends, and holidays. During this time, she was a member of the founding board of directors at the Canadian Museum of Civilization (now the Canadian Museum of History) where she directed the strategic planning process. She also served on the Social Sciences and Humanities Research Council of Canada (SSHRC) adjudication committee for Archaeology and as head of the Department of Anthropology at Memorial. In 1992, she received Memorial University's President's Award for Outstanding Research, and in 1996, she and Susan Kaplan founded LINK, an international group of scholars from a range of disciplines studying the interrelationships between climate and small-scale societies in the North Atlantic.

Among her many academic accomplishments, Priscilla was particularly gifted as a graduate student supervisor. Many of her incoming graduate students brought ideas and technical skills that Priscilla recognized and valued, so her relationships with them were mutually beneficial. Her respect for her students, fairness, and confidence in their abilities were an inspiration to them. None wanted to disappoint her, and all endeavored to meet the standard she had set through her own example. Priscilla saw her students through to completion using a mixture of firmness and humour. We recall her thorough and meticulous edits of our written work, which often included witty illustrations of trash cans filled with jargon and guns aimed at poorly worded phases.

Priscilla admitted that she neglected her personal life for many years, focusing solely on her career. This changed in 1996, when she met (and later married) Roger Pickavance, a Memorial University biologist and legendary cook. Roger supported her career at home as resident editor and accompanied her into the field, where he participated in her research and conducted his own. On occasion, he also filled in as cook, much to the delight of hungry field crews used to plainer fare. More significantly, with her beloved Roger, Priscilla realized the joys of a balanced life. Together they traveled for pleasure to France, where they co-owned a house with friends, and throughout the year they spent time at their property on the coast of Bonavista Bay. During the summer this little house, like their home in St. John's, became a hub of warm social gatherings with friends enjoying great food, wine, and conversation.

These were Priscilla's happiest years. Her career was evolving, with important opportunities to contribute to her discipline, and she developed a long and productive research collaboration with Trevor Bell, a geographer at Memorial University. On the basis of her strong research program, Priscilla was awarded a Tier 1 Canada Research Chair in North Atlantic Archaeology in 2001. In 2003, she became Chair of the founding board of directors of The Rooms Corporation of Newfoundland and Labrador, which brought together the province's museum, art gallery, and archives under one roof. In addition to her passion for archaeology, Priscilla shared with Roger a great love of visual art, and together they collected paintings and prints by many Newfoundland artists. Priscilla's work at The Rooms therefore brought her great personal pleasure. Toward the end of her life, Priscilla's stature as a researcher was such that she sat on the governing council of the SSHRC from 2008 until her death, and in 2010 she was made a Fellow of the Royal Society of Canada.

In addition to her many career highlights, Priscilla leaves another important legacy to our field. When she became a faculty member at Memorial in the early 1980s, Arctic archaeology was a particularly male-dominated specialty within an already male-dominated discipline. Priscilla, the strong-willed girl who grew into a productive, prominent woman scholar, helped to open up a space for other women in this realm. While she may not have written from an explicitly feminist standpoint, she showed students and younger colleagues that Arctic archaeologists did not have to be burly men with beards: women could run major northern field projects and become highly respected researchers in the field. This was yet another reason why she was a role model and an inspiration to many.

\section{INTRODUCTION TO THIS SPECIAL ISSUE OF ARCTIC}

To honour Priscilla Renouf's achievements, this issue brings together contributions from her students and colleagues around the world. Peter Rowley-Conwy was a student of Grahame Clark's at the same time as Priscilla, and they remained close colleagues and friends through the years. Trevor Bell was her long-standing research collaborator, examining past interactions between people and the landscape on Newfoundland's Great Northern Peninsula. Fred Dussault, John Erwin, and Lesley Howse were all students of Priscilla's who conducted independent research at Port au Choix. Gabriel Cooney, Max Friesen, Bjarne Grønnow, Susan Kaplan, Christyann and John Darwent, Vaughan Grimes (also her former student), Genevieve LeMoine, Marianne Stopp, Peter Toft, and Peter Whitridge were all her long-time colleagues. 


\section{Renaming the Palaeoeskimo Tradition}

Throughout her career, and in keeping with established archaeological practice of the time, Priscilla Renouf referred to the Pre-Dorset, Dorset, and transitional groups between the two, including Groswater, as members of the Palaeoeskimo (also spelled "Paleoeskimo," "PalaeoEskimo," and "Paleo-Eskimo") archaeological tradition. Archaeologists use "Palaeoeskimo" to distinguish these earlier occupants of the North American Arctic from a distinct later lineage, direct ancestors of modern Inuit, Inuvialuit, and Inupiat, whom archaeologists traditionally call "Thule" and assign to the "Neo-Eskimo" archaeological tradition. This latter group spread from Alaska into the Canadian Arctic and Greenland around AD 1200.

Inuit have long expressed their discomfort with the use of the term "Eskimo," a label given them by outsiders and often considered derogatory. The origins of the term are not clear. While many popular culture references suggest that "Eskimo" derives from an Algonquian word meaning "eaters of raw meat," linguists question this interpretation. Mailhot (1978) and Mailhot et al. (1980) suggest that it comes from Innu-aimun (Montagnais) words meaning "speaker of (the language of) a foreign land." Goddard (1984) suggests that it could derive from the Innu-aimun word assime $\cdot w$, which refers to the act of netting snowshoes, if Innu usage originally applied to other neighbouring Algonquian speakers and later shifted to the Inuit. The earliest appearances of "Esquimaux" in French support this interpretation since it refers variously to Inuit, Innu, and Mi'kmaq (Mailhot et al., 1980).

"Eskimo" is still common in Alaska, where it is used to encompass all Inupiat, Yup'ik, Sugpiaq (Alutiiq), and Unangan (Aleut) people, since the latter three are not Inuit language speakers and often prefer not to be labeled Inuit (Tabbert, 1989). Throughout Canada and Greenland, however, "Inuit" has largely replaced it. In 2010, the Inuit Circumpolar Council (ICC) passed a resolution urging researchers to adopt the use of "Inuit" instead of "Eskimo," and "paleo-Inuit" instead of "paleo-Eskimo," thereby recognizing the right of Arctic Indigenous people to selfidentify (ICC, 2010).

In the Canadian context, continued use of any term that incorporates "Eskimo" is potentially harmful to the relationships between archaeologists and the Inuit and Inuvialuit communities who are our hosts and increasingly our research partners. It is clearly time to rethink our terminology. Instead of replacing "Palaeoeskimo" and "Neo-Eskimo," it is possible in many cases to avoid them altogether and simply rely on specific terms such as "Dorset" and "Groswater" to refer to archaeological cultures. This approach works well in many contexts, but there will inevitably be cases where a collective term is required to describe the archaeological cultures that fall within these traditions.

Friesen (2015) argues that the Neo-Eskimo tradition should be formally renamed the "Inuit tradition," which seems entirely logical. Replacing "Palaeoeskimo" is more complex, and the contributors to this special issue do not all agree on the best way forward. Friesen (2015) proposes that we adopt "Paleo-Inuit" (meaning "old Inuit") because it follows the widespread practice of substituting "Inuit" for "Eskimo," accurately reflects the temporal relationship between the two traditions, and follows the ICC resolution. "Paleo-Inuit" now appears in a number of publications (e.g., Friesen and Mason, 2016; Landry et al., 2016; Seersholm et al., 2016). Some of the authors in this volume use the term for these reasons and in the interest of avoiding a confusing proliferation of terms.

The main objection to the use of "Paleo-Inuit" relates to the way people outside the archaeological community might interpret it. Archaeological evidence overwhelmingly indicates that Dorset and Thule Inuit were separate cultural entities. Though radiocarbon dates suggest some temporal overlap between Dorset and Thule Inuit in certain regions (Friesen, 2004; Friesen and Arnold, 2008; Appelt and Gulløv, 2009), recent DNA evidence indicates that the two populations were genetically distinct (Raghavan et al., 2014). Evidence of the clear biological separation between the two groups was not yet available at the time of the ICC resolution. Some might interpret "Paleo-Inuit" as suggesting not merely a chronological relationship between Paleo-Inuit and Inuit, but also a cultural or genetic relationship, or both.

What other terms could replace "Palaeoeskimo?" One approach might be to broaden the "Arctic Small Tool Tradition," which encompasses earlier Palaeoeskimo groups such as Pre-Dorset and Independence I, to include the Dorset. However, redefining an existing term might only add to the confusion. Instead, some of the authors in this volume adopt "pre-Inuit," since it accurately reflects the temporal relationship with Inuit and does not imply a cultural or genetic relationship.

There are also Inuktitut options that warrant consideration, particularly as archaeologists work increasingly closely with Inuit in understanding the Arctic past. "Tuniit" (sometimes spelled Tunit or Tunnit) is used by the Inuit Heritage Trust (2014a, b, c), and some archaeologists use the term to refer to Dorset groups, and sometimes also to earlier related groups such as the PreDorset. Tuniit are people who figure in many Inuit stories: sometimes they are described as little people, other times as giants. Often they are said to have occupied the land before the Inuit arrived and been killed by the ancestors of the Inuit, though in some accounts they are still around today. Inuit Tapiriit Kanatami (2004:7) makes a distinction between Tuniit, who are sometimes portrayed as "just a different kind of Inuk" and sometimes "as not being the same as the real Inuk," and the earliest real ancestors of Inuit, whom they term Sivullirmiut, which means "the first ones." Because in some cases Tuniit are not understood as human, it may not be the best choice for renaming this archaeological tradition. 
Archaeological typologies employ standardized terminology and are necessarily conservative. The current need to rethink our terminology comes at a time when public engagement is increasingly important for archaeologists because federal funding councils are encouraging better communication of our research aims and results to the broader public. It therefore seems wise to choose a term that most effectively conveys temporal, cultural, and genetic relationships between groups. It is equally important that any new terminology reflect and respect Inuit understandings of their history so that archaeologists can continue to build productive research partnerships with Inuit.

Clearly, the question of an appropriate replacement for "Palaeoeskimo" remains unresolved among archaeologists, and further discussion is warranted to try to achieve consensus. It behooves us to engage Inuit organizations in this conversation as well, so that we are not secondguessing Inuit understandings and wishes. Because its direct translation does not imply any direct cultural or genetic relationship with Inuit, "Sivullirmiut" may be a term around which we can build such consensus. As an Inuktitut word, it can help to acknowledge the special relationship between Inuit and the Arctic past. The intimate relationship between Inuit identity and the land means that, regardless of the genetic evidence, Inuit share strong ties with any group that occupied their traditional territoryand Inuit may understand Sivullirmiut as their ancestors, at the same time as archaeologists wish to make a clear distinction between the two groups.

\section{Overview of Papers in the Special Issue}

The papers gathered here pick up on many of the abiding themes of Priscilla's research. Her earlier work focused on the distinctive features of northern coastal hunter-gatherers, who often display a higher degree of sedentism, larger population aggregations, higher reliance on food storage, and stronger tendencies towards territoriality and social differentiation than terrestrial hunter-gatherers from lower latitudes. Rowley-Conwy and Piper build on such earlier work, suggesting that in framing northern coastal huntergatherers as distinctive, archaeologists have overlooked models derived from terrestrial hunter-gatherers that might be usefully applied to northern coastal groups, and vice versa. They argue that the Saxe-Goldstein hypothesis could allow us to distinguish between semi-sedentary groups that practice territoriality and those that do not on the basis of their treatment of the dead. They also highlight the potential importance of boats among interior groups, where their use in lake and river systems could facilitate colonization of new areas and far-flung social interactions.

The bulk of Priscilla's work at Port au Choix focused on the unusually large Dorset site of Phillip's Garden. Her investigations revealed both short- and long-term variability in architecture, household structure, and settlement organization at the site over its 800 -year history of occupation. John Darwent et al. elucidate a similarly long and complex settlement history at Shaktoolik in Alaska. Their program of mapping and test excavation provides some of the first evidence of possible cultural continuity from the early archaeological Nukleet culture to ethnographically known Yup'ik peoples. Furthermore, their careful consideration of house forms, material culture, ethnography, and oral history strongly indicates Yup'ik occupation of the site from the 1400 s through the mid 1800 s, when an abrupt change in house form suggests the arrival of Inupiat groups from the north.

Much of Priscilla's work examined the role of material culture in traditional small-scale societies, with a particular focus on Newfoundland. John Erwin and Marianne Stopp explore these processes on Priscilla's "home turf" in Newfoundland and Labrador. Erwin's analysis of soapstone vessels from Newfoundland and Labrador suggests that Groswater and Dorset participated in a broad regional interaction network. This interpretation is supported by evidence for temporal trends in vessel form across the region and by current evidence suggesting that all of the soapstone vessels in the province could originate from the quarry at Fleur de Lys. At the same time, certain rim finishes appear to be characteristic of Newfoundland vs. Labrador sites, suggesting distinctive manufacturing traditions in these two sub-regions. Stopp similarly argues for region-wide social connections between northwestern Newfoundland and southern Labrador. She points to archaeological evidence of long-distance trade in tool stone from Labrador to Newfoundland, and vice versa, and of harp seal hunting in complementary seasons (primarily early winter in Labrador and spring in Newfoundland) to support this assertion. She suggests that their mobility and far-reaching social connections were central to the longterm continuity of Dorset occupation in the region.

Gabriel Cooney examines similar processes on the other side of the Atlantic, reconstructing how Neolithic peoples' engagement with stone sources served to create relationships and identities through a study of the biographies of stone axes from three island quarries in Ireland and Scotland. On the basis of the three cases he presents here, Cooney argues that peoples' engagement with these sources was specific to the particular resources and history of each island and reflected unique exchange networks and identities that operated at different spatial scales.

Priscilla's work also focused on interactions between people and their environments, exploring the interrelationships between environmental and cultural change, the impact of people on their environments, and how distinct cultural groups exploited the same environment. Dussault et al. build on Priscilla's earlier work with Trevor Bell and colleagues, which examined these human-environment interactions at Port au Choix using a range of proxies to document temporal shifts in pond ecology in areas of human occupation. Dussault et al.'s study of beetle remains from Phillip's Garden indicates 
that intensive Dorset occupation of the site changed local soils and hydrology, making the site wetter over time. It further suggests that a forested environment surrounded the site during the early and late phases of occupation, but not during the most intensive middle phase, and that the site's occupants actively harvested trees for firewood and other purposes during the early and late phases. Howse and Friesen explore the theme of unique adaptations to a single environment by different cultural groups, comparing Dorset and Thule Inuit subsistence at Iqaluktuuq on Victoria Island. While subsistence is broadly similar in the two groups, with a strong emphasis on caribou and char, there are some important differences. Dorset subsistence appears to be more diversified than that of the Thule Inuit, with a greater reliance on secondary species and younger individuals. The authors suggest that this more "selective" approach may relate to the more sophisticated and diverse technology of the Thule.

Priscilla was also interested in the cultural entanglements of different cultural groups that simultaneously occupied the same landscape, and she published work on the relationships of Groswater and Dorset with Recent Indian groups in Newfoundland. Three of the papers in this special issue deal with similar cultural interactions between Inuit and either European or EuroAmerican settlers in Greenland. Toft examines the mutual influences of Greenland Inuit and Moravian missionaries during the tenure of Moravian missions in the region from 1733 to 1900 . He documents how these interactions transformed settlement layout, cemetery location, grave forms, and material culture. He shows that mission gardens were not always placed in front of the church in accordance with Moravian ideals, that Inuit-produced souvenirs often incorporated European styles, and that the distance between Inuit graves and Moravian settlements decreased over time. Grønnow investigates Inughuit lifeways in the Avanersuaq region from 1910 to 1953, when Thule Station, a Danish trading post, was active. He shows that Inughuit practiced a high degree of mobility, exploiting and storing a range of animal resources at seasonal hunting grounds across the district. They capitalized on the European trading presence, which facilitated and encouraged increased reliance on dog sledges. Inughuit families generally dispersed in the winter, often spending part of the season at Thule Station, before gathering at important walrus-hunting sites in spring. LeMoine et al. examine the responses of Inughuit women, hired to sew clothing for Peary's North Pole expeditions, to interactions with male Euro-American explorers in the early 20th century. They argue that these women experienced considerable stress while at Peary's base camp. Contemporary accounts suggest that many experienced mental health issues, and archaeological evidence indicates they had to improvise alcohol-burning lamps and stoves from tin cans. This situation contrasts sharply with contemporaneous archaeological evidence from the Inughuit settlement at Iitah, where women continued to use traditional lamps and Inughuit families selectively adopted
European technologies while maintaining their own way of life.

Priscilla recognized the importance of different analytical scales in understanding past hunter-gatherers, often working at multiple and shifting spatial scales from feature, dwelling and site, to region. Whitridge draws inspiration from these nested analytical scales in attempting to reconstruct precontact Inuit scales of thought and action by examining their miniature carvings and incised representations. He suggests that these miniatures provide a window into the imagined worlds of the people who made and used them. The frequency of miniature human forms, at a range of scales representing real humans at various distances and ages, leads Whitridge to propose that the human body was an important organizing principle in Inuit art, thought, representation, and imagination.

These wide-ranging articles reflect the thematic breadth of Priscilla's research and provide a fitting tribute to her remarkable career. Through them, we celebrate her memory and build on her contributions.

\section{ACKNOWLEDGEMENTS}

Many thanks to Karen McCullough for guidance, patience, and good judgement throughout the editorial process. We know that this special issue added considerably to her workload and that of her associates and appreciate their efforts. We are grateful to all of the authors for their submissions and revisions, and to the reviewers for their time and insights-the contributions to this issue are better for their efforts. Thanks also to those not published here who contributed to the session in honour of Priscilla at the 2015 Canadian Archaeological Association annual meeting in St. John's: Claire Alix, Martin Appelt, Jenneth Curtis, Murielle Nagy, Ulla Odgaard, Peter Pope, Maribeth Murray, Christina Robinson, Karen Ryan, and Jim Woollett.

The online production of this special issue of Arctic was made possible with generous contributions from Parks Canada and Roger Pickavance, with additional support from a Natural Sciences and Engineering Research Council Discovery grant awarded to Trevor Bell and a SSHRC Insight grant awarded to Lisa Hodgetts.

Most of all thanks to Priscilla, Queen of the Dorset, who helped us discover Sivullirmiut archaeology, inspired us to persist through adversity, and made us laugh. We are better scholars for having worked with her, and better people for having known her.

\section{REFERENCES}

Appelt, M., and Gulløv, H.C. 2009. Tunit, Norsemen, and Inuit in thirteenth-century northwest Greenland-Dorset between the devil and the deep sea. In: Maschner, H., Mason, O., and McGhee, R., eds. The Northern World AD 900-1400. Ann Arbor: University of Michigan Press. 300-320. 
Friesen, T.M. 2004. Contemporaneity of Dorset and Thule cultures in the North American Arctic: New radiocarbon dates from Victoria Island, Nunavut. Current Anthropology 45(5):685-691.

- 2015. On the naming of Arctic archaeological traditions: The case for Paleo-Inuit. Arctic 68(3):iii-iv. https://doi.org/10.14430/arctic4504

Friesen, T.M., and Arnold, C.D. 2008. The timing of the Thule migration: New dates from the western Canadian Arctic. American Antiquity 73(3):527-538.

Friesen, T.M., and Mason, O.K., eds. 2016. The Oxford handbook of the prehistoric Arctic. New York: Oxford University Press.

Goddard, I. 1984. Synonymy. In: Damas, D., ed. Handbook of North American Indians, Vol. 5: Arctic. 5-7.

Inuit Circumpolar Council. 2010. Inuit Circumpolar Council Resolution 2010-01 on the use of the term Inuit in scientific and other circles.

http://www.inuitcircumpolar.com/uploads/3/0/5/4/30542564/ iccexcouncilresolutiononterminuit.pdf

Inuit Heritage Trust. 2014a. A guide to Nunavut archaeology and artifacts for northern communities. Iqaluit: IHT.

http://www.ihti.ca/eng/IHT-Archaelogy-Artifacts-GuidebookCommunities-English-Web-Opt.pdf

- 2014b. A guide to Nunavut archaeology and artifacts for northern heritage workers. Iqaluit: IHT.

http://www.ihti.ca/eng/IHT-Archaelogy-Artifacts-GuidebookHeritageWorkers-English-Web-Opt.pdf

- 2014c. A guide to Nunavut archaeology and artifacts for northern students. Iqaluit: IHT.

http://www.ihti.ca/eng/IHT-Archaelogy-Artifacts-GuidebookStudents-English-Web-Opt.pdf
Inuit Tapiriit Kanatami. 2004. Inuit history and heritage. Ottawa: ITK.

https://www.itk.ca/wp-content/uploads/2016/07/5000YearHeri tage_0.pdf

Landry, D.B., Milne, S.B., Park, R.W., Ferguson, I.J., and Fayek, M. 2016. Manual point cloud classification and extraction for hunter-gatherer feature investigation: A test case from two Low Arctic Paleo-Inuit sites. Open Archaeology 2(1):232-242. https://doi.org/10.1515/opar-2016-0017

Mailhot, J. 1978. L'étymologie de "Esquimau:" Revue et corrigée. Etudes/Inuit/Studies 2(2):59-70.

Mailhot, J., Simard, J.-P., and Vincent, S. 1980. On est toujours l'Esquimau de quelqu'un. Etudes/Inuit/Studies 4(1-2):59-76.

Raghavan, M., DeGiorgio, M., Albrechtsen, A., Moltke, I., Skoglund, P., Korneliussen, T.S., Grønnow, B., et al. 2014. The genetic prehistory of the New World Arctic. Science 345(6200): 1255832.

https://doi.org/10.1126/science.1255832

Seersholm, F.V., Pedersen, M.V., Søe, M.J., Shokry, H., Mak, S.S.T., Ruter, A., Raghavan, M., et al. 2016. DNA evidence of bowhead whale exploitation by Greenlandic Paleo-Inuit 4,000 years ago. Nature Communications 7: 13389. https://doi.org/10.1038/ncomms13389

Tabbert, R. 1989. The names Eskimo, Inuit, and Inupiaq/Inupiat. Names 37(1):79-82.

https://doi.org/10.1179/nam.1989.37.1.79 